PREGLEDNI RAD - REVIEW

\title{
Utjecaj pripremnih tehnika i termičkih postupaka procesiranja na sadržaj ostataka pesticida u namirnicama
}

\section{Effect of preparatory steps and thermal processing on pesticide residues in food}

\author{
Marina Miletić ${ }^{1}$, Teuta Murati*, Ada Puntarić1, Nina Bilandžić2 ${ }^{1 *}$ Ivana Kmetič ${ }^{1}$ \\ ${ }^{1}$ Prehrambeno-biotehnološki fakultet Sveučilišta u Zagrebu, Laboratorij za toksikologiju, Pierottijeva 6, 10000 Zagreb, \\ Hrvatska \\ ${ }^{2}$ Hrvatski veterinarski institut, Laboratorij za određivanje rezidua, Savska cesta 143, 10000 Zagreb, Hrvatska \\ *Corresponding author: tmurati@pbf.hr
}

Sažetak

Suvremena proizvodnja prehrambenih proizvoda gotovo je nezamisliva bez upotrebe pesticida. Porast kontaminacije hrane ostacima pesticida je doveo do povećane potrebe za otkrivanjem načina za njihovo uklanjanje. Brojne tehnike procesiranja hrane, bilo u industriji ili u kućanstvima, mogu dovesti do promjene njihovog sadržaja u namirnici. Njihovo uklanjanje iz namirnice ovisi o kemijskim karakteristikama pesticida te vrsti namirnice u kojoj se nalaze kao i o načinu procesiranja namirnice. Razni pripremni (pranje vodom ili otopinama, guljenje) te termički postupci obrade (pasterizacija, blanširanje, kuhanje, prženje, pečenje) koji se koriste u procesima pripreme hrane mogu dovesti do promjene (najčešće smanjenja) sadržaja ostataka pesticida. U ovom radu prikazan je utjecaj najzastupljenijih pripremnih tehnika te termičkih postupaka procesiranja namirnica na sadržaj ostataka pesticida u krajnjim proizvodima.

Ključne riječi: hrana, pesticidi, pranje, guljenje, termičko procesiranje, faktor procesiranja

Abstract

Modern food production is almost unimaginable without the use of pesticides. Increased contamination of food with pesticide residues has led to an increased need to detect methods to remove them. Numerous food processing techniques, either in industry or in households, can lead to a reduction of their content in foods. Their removal from foodstuffs depends on the chemical characteristics of pesticides, type of food matrix and the way food is processed. Various preparation techniques (washing with water or solutions, peeling) and thermal processing (pasteurisation, blanching, cooking, frying, baking) used in food preparation processes can lead to a change (mostly reduction) of pesticide residues. This paper presents an overview of the most common preparation and thermal techniques of food processing on the contents of pesticide residues in end products.

Keywords: food, pesticides, washing, peeling, thermal processing, processing factor

\section{Uvod}

U današnje vrijeme - doba izrazitog rasta populacije popraćenog s povećanjem obradivih površina, došlo je do povećane potrebe za porastom prinosa prilikom proizvodnje hrane. To je osigurano, između ostalog, kroz intenzivnu upotrebu pesticida, koji tako doprinose uspješnijim berbama usjeva $\mathrm{s}$ istovremenim minimalnim gubitcima prilikom skladištenja (Đorđević i Đurović-Pejčev, 2016). Upotreba pesticida ima dosta dugu i relativno slabo dokumentiranu povijest korištenja, ali je poznato kako su se ljudi oduvijek borili s mnogobrojnim štetnim organizmima, koji su im posljedično donijeli velike ekonomske gubitke. Pesticide se može definirati na razne načine i svaki od njih ima neke posebne značajke, ali ono što im je svima zajedničko jest da posjeduju svojstvo uništavanja ili ubijanja određenog štetnika. Univerzalna definicija navedena je u dokumentu Organizacije za prehranu i poljoprivredu Ujedinjenih naroda (engl. FAO - Food and Agriculture Organization of the United Nations) nazvanom International Code of Conduct on the Distribution and Use of Pesticides (FAO, 2005): „Pesticid je bilo koja tvar ili mješavina tvari namijenjena sprječavanju, uništavanju ili suzbijanju bilo kojeg štetnika, kao što su prenositelji bolesti u ljudi ili životinja, neželjene vrste biljaka ili životinja koje uzrokuju štetu tijekom proizvodnje, prerade, pohranjivanja, transporta ili trgovine hranom, poljodjelskim proizvodima, drvetom i drvnim proizvodima kao i stočnom hranom“. Pesticid je pripravak kojeg čine aktivna tvar, tj. kemijski spoj (ili više njih) pesticidnog djelovanja i nosač - inaktivna tvar bez pesticidnog djelovanja (NPIC, 1999). Primjena pesticida obuhvaća 
razna područja ljudske djelatnosti. Najveći dio pesticida se koristi za zaštitu bilja u poljodjelstvu (sredstva za zaštitu bilja, 50-90\%), nakon toga za proizvodnju i skladištenje ljudske i stočne hrane te za zaštitu industrijskog i ukrasnog bilja. Primjenjuje se također i u stočarstvu, veterinarskoj djelatnosti i raznim drugim područjima (Puntarić i sur., 2012). Približno $70 \%$ pesticida korištenih u svijetu se primjenjuje u razvijenim zemljama, dok se njih 30\% koristi u zemljama u razvoju (Bajwa i Sandhu, 2014). Akutna i kronična izloženost pesticidima može narušiti ljudsko zdravlje (Murati i sur., 2014; Hu i sur., 2015; Đorđević i Đurović-Pejčev, 2016), a opasnost većinom potječe od aktivne tvari pesticida, no i nosač može biti opasan ukoliko pripada skupini otrovnih organskih otapala. Često se zaboravlja kako su zapravo vrlo malene frakcije primijenjenih pesticida uključene u mehanizam njihova djelovanja na usjevima. Prekomjerna upotreba, zloupotreba $\mathrm{i} /$ ili neselektivna upotreba pesticida, posebno u zemljama $\mathrm{u}$ razvoju, njihova hlapljivost $\mathrm{i}$ transport na vrlo velike udaljenosti u konačnici mogu rezultirati nepoželjnim ostacima pesticida koji mogu zaostati na poljoprivrednim proizvodima, ući u hranidbeni lanac gdje se biokoncentriraju (akumuliraju u pojedinim organizmima) i biomagnificiraju (sukcesivno im je povećana koncentracija u tkivima organizama na višim razinama hranidbenog lanca) te tako predstavljaju opasnost (Kaushik i sur., 2009; Đorđević i Đurović-Pejčev, 2016).

Bilo koja tvrtka koja planira plasirati pesticid na tržište treba ga registrirati u skladu s važećim zakonodavstvom u zemlji u kojoj se provodi registracija. U cilju prijavljivanja proizvoda, tvrtka mora predočiti rezultate toksikoloških istraživanja koji pokazuju učinkovitost pesticida protiv ciljanih štetnika te njihovo neškodljivo djelovanje na ljudsko ili životinjsko zdravlje te okoliš. Istraživanja obuhvaćaju sve potencijalne načine unosa pesticida: oralno, kontaktno i udisanjem. Na temelju dobivenih toksikoloških podataka, određuje se najviša doza koja još uvijek ne uzrokuje promatrani/toksični učinak - NOAEL (engl. no observed adverse effect level), a testiranja se provode dugotrajno na najosjetljivijim životinjskim vrstama i na vrstama koje su slične čovjeku (Cabras, 2003). Kada je o pesticidima riječ, sigurnosne su im granice izražene pojmovima akutna referentna doza (ARfD - engl. acute reference dose) i prihvatljivi dnevni unos (ADI - engl. acceptable daily intake), a predstavljaju količinu pesticida koja može biti konzumirana u kratkom vremenu ili tijekom cijelog života bez rizika za zdravlje potrošača (Nasreddine i Parent-Massin, 2002). ADI se dobiva dijeljenjem NOAEL vrijednosti s faktorom sigurnosti koji varira u vrijednostima između 20 i 10000 (Puntarić i sur., 2012). Tretman sredstvima za zaštitu bilja može dovesti do potencijalno različitih ostataka u hrani unatoč usklađenosti s njihovim autoriziranim specifičnim nanošenjem u uvjetima dobre poljoprivredne prakse (GAP - engl. Good Agricultural Practice). GAP se brine o apliciranim dozama sredstava za zaštitu bilja i vremenskim intervalima između njihove primjene i žetve usjeva (karenca). Ako ti uvjeti nisu zadovoljeni, ubrani usjevi mogu sadržavati nedopustive razine ostataka sredstava za zaštitu bilja (González-Rodrígez i sur., 2011). Prehrambeni proizvodi postaju sigurni za konzumaciju samo nakon isteka karenca. Ako se voće i povrće ili neki drugi prehrambeni proizvod ubere prije završetka karence, on će vrlo vjerojatno sadržavati veću količinu ostataka sredstava za zaštitu bilja koji mogu biti potencijalno opasni za zdravlje (Bajwa i Sandhu, 2014). Stoga je za pesticide vrlo bitna vrijednost maksimalne količine ostataka (MRL - engl. maximum residue level; izražena u miligramima po kilogramu proizvoda na koji se primjenjuje) koja je legalno dopuštena u hrani i životinjskom krmivu. Količina ostataka pesticida u prehrambenim proizvodima je određena zakonom u cilju smanjenja izloženosti potrošača pesticidima, osiguranja pravilne primjene pesticida te slobodnog kretanja proizvoda koji su tretirani pesticidima (Nasreddine i Parent-Massin, 2002). MRL vrijednost je vjerodostojno i korisno sredstvo za provedbu prihvatljivog korištenja pesticida. Međutim, korištenje MRL-a se pokazalo neadekvatnim kao pokazatelj za količinu ostataka pesticida kojima je čovjek izložen putem hrane (Amvrazi, 2011). Prilikom analize studija u kojima je kao osnovni pokazatelj procjene unosa ostataka pesticida hranom korišten MRL, uočeno je precjenjivanje stvarnog unosa. Svjetska zdravstvena organizacija (WHO, eng. World Health Organization) je zato preporučila drugačiji pristup za procjenu rizika od izloženosti pesticidima putem hrane koji uključuje činjenicu da se namirnice većinom procesiraju u industriji i kućanstvima prije same upotrebe. Različiti postupci procesiranja namirnica utječu na konačnu količinu ostataka u njoj $\mathrm{i}$ to putem kemijskih i biokemijskih reakcija (hidroliza, oksidacija, mikrobna degradacija, ...) te fizikalno-kemijskih procesa (isparavanje, adsorpcija, ...) (Amvrazi, 2011). Tako, npr. sadržaj ostataka pesticida zaostao na usjevima uobičajeno opada prilikom transporta, skladištenja, pripreme i procesiranja (Timme i Walz-Tylla, 2004). Stoga je od velikog značaja upotreba jednostavnih, jeftinih i efikasnih pripremnih metoda, kao i metoda procesiranja hrane i u industriji i u kućanstvima, zbog utjecaja na ukupan sadržaj ostataka pesticida u hrani (Kaushik i sur., 2009).

\section{Mehanizmi i faktori koji utječu na lokalizaciju i promjenu količine ostataka pesticida u hrani}

Nakon što se sredstva za zaštitu bilja primjene na usjevima ona zaostaju na njima, a njihove razine moraju biti niže od zakonskih ograničenja prilikom berbe usjeva. Pod pojmom ostaci pesticida se ne misli samo na ostatke aktivnih tvari pesticida u hrani, nego i na njihove metabolite i/ili produkte razgradnje i toksikološke nečistoće u samoj formulaciji pesticida. Količina ostataka sredstava za zaštitu bilja prisutnih na voću i povrću prilikom berbe ovisi o prvotno zaostaloj koncentraciji pesticida nakon primjene i stopi smanjenja ostataka pesticida (Cabras, 2003). Postoji mnogo čimbenika koji utječu na stupanj apsorpcije, penetracije i degradacije pesticida i razlikuju se između samih kategorija namirnica na kojima se pesticidi primjenjuju. Stopa smanjenja početne količine primijenjenih pesticida je također povezana s fizikalno-kemijskim svojstvima pesticida i okolišnim uvjetima. Sposobnost pesticida da se odupre degradaciji pod različitim uvjetima je izražena poluživotima pesticida. Poluživot je vrijeme potrebno da se polovica početne aplicirane količine pesticida raspadne, odnosno nestane. Poluživot pesticida može varirati od nekoliko sati ili dana do godina za one otpornije. Vrijeme poluživota se procjenjuje i može se mijenjati s obzirom na vanjske okolišne uvjete. Pesticidi se mogu raspadati uslijed procesa fotolize, hidrolize, oksidacije i redukcije, enzimskom degradacijom - metabolizmom 
(biljke, životinje ili mikroorganizmi), djelovanjem temperature i pH. Osim vanjskih okolišnih uvjeta, na vrijednosti poluživota utječe i početna primijenjena količina pesticida, vrsta i formulacija pesticida te vrsta, veličina i oblik namirnice na kojoj se primjenjuje pesticid.

Pesticidi su većinom lipofilni i mogu vršiti svoju aktivnost u kontaktu ili sistemski. Ako ostaci pesticida prodiru unutar usjeva, oni se razgrađuju različitim mehanizmima, a ukoliko zaostanu na površinskim slojevima, uglavnom prolaze redukcijske procese povezane s okolišnim uvjetima kao što su pranje, isparavanje i fotodegradacija (Cabras, 2003). Upravo zbog toga što većina organskih pesticida ima veliki afinitet za ulja i masti, njihovo uklanjanje je iznimno teško (Bajwa i Sandhu, 2014).

Hrana nakon berbe/klanja je podređena raznim operacijama rukovanja i prerađivanja koje uključuju jednostavno pranje, ali i kompleksnije operacije prerađivanja u više koraka (Bajwa i Sandhu, 2014). Procesiranje hrane se uglavnom odnosi na transformaciju kvarljive robe u proizvod koji nakon toga ima dulji rok trajanja te mu je tako dana dodatna vrijednost (Kaushik i sur., 2009). Procesiranje uz pranje podrazumijeva, uklanjanje (ne)jestivih dijelova (guljenje, podrezivanje), blanširanje, kuhanje ili neki drugi oblik procesiranja na kemijskoj razini (González-Rodrígez i sur., 2011). Zbog fizikalno-kemijskih svojstava pesticida, njegova koncentracija može se uslijed procesiranja namirnice smanjiti ili povećati u usporedbi s početnom koncentracijom u sirovoj namirnici (RAC, eng. raw agricultural commodity). Omjer između količine ostataka pesticida u procesiranoj hrani i razine ostataka u RAC definiran je kao faktor procesiranja ( $\mathrm{P} f$, eng. processing factor) (Amvrazi, 2011; Scholz i sur., 2017). Očekivano je kako će se procesiranjem hrane uglavnom smanjiti udio pesticida. No, u nekim slučajevima razina ostataka pesticida može i narasti u finalnom proizvodu zbog koncentriranja sirovih sastojaka prilikom procesiranja. Koncentriranje sastojaka može biti povezano s uklanjanjem vode iz proizvoda ili s akumulacijom lipofilnih aktivnih tvari pesticida u masnoj frakciji hrane (González-Rodrígez i sur., 2011). Tako prilikom proizvodnje mliječnih proizvoda $\mathrm{s}$ višim udjelom masti u krajnjem proizvodu nego u sirovini (mlijeku), ostaci pesticida topljivih u mastima se tijekom procesiranja povećavaju (González-Rodrígez i sur., 2011). Poseb$\mathrm{nu}$ pozornost $\mathrm{s}$ obzirom na razinu ostataka $\mathrm{u}$ konačnom proizvodu treba usmjeriti i na nerafinirano ulje jer je smanjenje ostataka pesticida tijekom njegove proizvodnje nisko za većinu pesticida topljivih u mastima, a faktor procesiranja se kreće od 2 do 7 (Amvrazi, 2011).

Najvažniji mehanizmi koji mogu dovesti do moguće promjene količine ostataka pesticida tijekom skladištenja i pripreme hrane kod kuće ili u industriji su: otapanje, degradacija pod utjecajem topline, hidroliza, enzimska transformacija/mikrobna degradacija, oksidacija, penetracija, fotodegradacija, isparavanje i ko-destilacija, promjena koncentracije ostataka pesticida uslijed promjena težine RAC (Amvrazi, 2011).

U današnje vrijeme sve je veći interes, kako javnosti, tako i regulatornih tijela, za utjecaj različitih procesa na količinu ostataka pesticida u namirnici. Stoga će se u daljnjem tekstu detaljnije opisati utjecaj pripremnih koraka te termičkih postupaka prerade hrane na ukupan sadržaj ostataka pesticida u hrani.

\section{Učinak pripremnih koraka obrade namirnica na sadržaj pesticida}

Pripremni koraci obrade namirnica obuhvaćaju pranje (vodom, slanim otopinama te kemijskim otopinama) te guljenje odnosno odstranjivanje pojedinih dijelova. Pripremnim koracima se najčešće izlaže voće i povrće.

\section{Pranje vodom - učinak na sadržaj pesticida}

Pranje je najčešći i najjednostavniji oblik procesiranja hrane koji je kao pripremni korak obavezan i u industriji i u kućanstvima (Kaushik i sur., 2009). Bilo da se poslije toga hrana konzumira sirova ili se dodatno obrađuje, korak pranja je vrlo bitan jer njime dolazi do smanjivanja sadržaja ostataka pesticida u velikom udjelu. Učinkovitost ispiranja ostataka pesticida ovisi o nekoliko čimbenika: lokaciji ostataka u namirnici i njihovoj starosti, topljivosti pesticida, vrsti/temperaturi otopine koja se koristi za pranje (Holland i sur., 1994; Kaushik i sur., 2009; Đorđević i Đurović-Pejčev, 2016). Smanjenje ostataka presticida je posebice izraženo za pesticide koji su topljivi u vodi, kao i za one koji su ograničeni u kretanju unutar namirnice i slabije penetriraju u namirnicu (Đorđević i Đurović-Pejčev, 2016). U istraživanju koje su proveli EL-Saeid i Selim (2016) početne koncentracije ostataka metomila, endosulfana II, dikofola, dimetoata, pirimifos metila, cipermetrina i metalaksila u slatkoj paprici su iznosile redom $0,487,0,007,0,007,0,013,0,020,0,0186$ i $0,156 \mathrm{ppm}$. Nakon pranja vodom iz slavine postotak smanjenja ostataka iznosio je $59 \%, 49 \%, 67 \%, 15 \%, 10 \%, 65 \%$ i $30 \%$. Kumari (2008) je u istraživanju učinaka različitih procesa pripreme u kućanstvu na udio ostataka pesticida na povrću pokazao da je pranjem vodom došlo do smanjenja ostataka organokloriranih pesticida za $27-44 \%$ u patlidžanu, $34-36 \%$ u cvjetači te $20-38 \%$ u bamiji. Kod korištenja sintetskih piretroida na istim kulturama došlo je do smanjenja ostataka pesticida za $26 \%$ (patlidžan), 29\% (cvjetača) i 31\% (bamija), dok je do najvećeg smanjenja došlo kod primjene organofosfornih pesticida (smanjenje za 77\%, 74\% i 50\%).

No, mogućnost ispiranja pesticida nije uvijek povezana s njihovom topljivošću u vodi (Amvrazi, 2011). Ostaci sistemičnih pesticida prisutni u biljnim tkivima će uvijek biti vrlo malo zahvaćeni operacijama pranja. Također, postoji mnogo dokaza koji pokazuju kako kod mnogih vrsta pesticida i različitih usjeva proporcija ostataka pesticida koja se može ukloniti pranjem opada s vremenom. To se objašnjava tendencijom pesticida da migriraju u voštane i dublje slojeve i tako bivaju zaštićeni od utjecaja vode (Ahmed i sur., 2011). Dodatan kontradiktoran podatak o učinkovitosti pranja kao sredstva za većinsko uklanjanje ostataka pesticida jest višestruko pranje maslina, gdje je samo kod prvog pranja došlo do određenog smanjivanja ostataka pesticida, dok je kod drugih pranja, koja su čak i dulje trajala nego prvo pranje, količina ostataka ostala nepromijenjena. To se može objasniti stanjem ploda u trenutku primjene sredstva za zaštitu bilja. Ako je na voću ili povrću bilo prašine, aktivni sastojci će se razložiti na voštane slojeve na površini voća/povrća i na čestice prašine. Prašina će se ukloniti s plodova tijekom pranja i što je veća količina ostataka pesticida povezana s česticama prašine to će oni biti uklonjeni u većoj mjeri (Cabras, 2003). 


\section{Pranje otopinama - učinak na sadržaj pesticida}

Iako se pranje vodom iz slavine pokazalo kao vrlo jednostavna, korisna, učinkovita i prikladna metoda za uklanjanje ostataka pesticida s površine namirnica, dokazano je kako je pranje otopinama još učinkovitije i može dovesti do još većih gubitaka ostataka pesticida (Đorđević i Đurović-Pejčev, 2016).

Natrijev klorid $(\mathrm{NaCl})$ se često koristi kao sredstvo za smanjenje sadržaja ostataka pesticida u različitom voću i povrću (Ahmed i sur., 2011). Metoda korištenja slanih otopina može biti jednako učinkovita za uklanjanje ostataka pesticida i s drugih namirnica te se zbog praktičnosti preporuča za korištenje u kućanstvima (Bajwa i Sandhu, 2014). Razne otopine koje se još koriste za snižavanje sadržaja pesticida u prehrambenim proizvodima mogu biti kiselog (otopine octene kiseline, limunske kiseline, askorbinske kiseline, $\mathrm{H}_{2} \mathrm{O}_{2}$ ili otopine vodenog ekstrakta lišća rotkvica...) te lužnatog karaktera (otopine $\mathrm{NaOH}$, detergenta, sapuna, $\mathrm{NaHCO}_{3}$, ozonirane i klorirane vode, kalijeva dikromata...) (Ahmed i sur., 2011; Bajwa i Sandhu, 2014). U istraživanju na rajčicama koje su bile podvrgnute pranju otopinama različitog $\mathrm{pH}$ dokazano je da je prilikom pranja 10\%-tnom otopinom octene kiseline i 10\%-tnom otopinom NaCl-a došlo do nekoliko puta većeg smanjenja ostataka lindana, $p, p$-DDT-a, dimetoata, profenofosa i pirimifos-metila u usporedbi s pranjem vodom iz slavine (Abou-Arab, 1999b). Općenito se smatra kako kisele otopine daju bolje rezultate od pranja neutralnim i alkalnim otopinama (Ahmed i sur., 2011).

Detergenti imaju sposobnost otopiti voskove na površini voća/povrća i tako utjecati na smanjenje ostataka pesticida prisutnih u voštanom sloju ploda (Amvrazi, 2011). Ozonirana voda je također učinkovita u uklanjanju ostataka pesticida zbog svojih oksidirajućih svojstava. Sigurna je za korištenje i uklanjanje ostataka pesticida s površine povrća u kućanstvima (Ahmed i sur., 2011). Tako je kod pranja brokule ozoniranom vodom došlo do većeg smanjenja $\alpha$-cipermetrina, azoksistrobina, boskalida, klorpirifosa i drugih pesticida nego kod pranja vodom iz slavine (Łozowicka i Jankowska, 2016). Takvi dobiveni rezultati su dobar pokazatelj potencijala korištenja otopina za smanjenje/uklanjanje ostataka pesticida na voću i ostalim namirnicama (Kaushik i sur., 2009).

\section{Guljenje, ljuštenje - učinak na sadržaj pesticida}

Velika većina kontaktnih sredstava za zaštitu bilja koja se direktno primjenjuju na usjevima ne prelazi u dublje slojeve, zbog čega su ostaci tih tvari većinom prisutni na vanjskim površinama gdje su podložni uklanjanju guljenjem, ljuštenjem ili podrezivanjem (Ahmed i sur., 2011). Bilo da se radi o kemijskom guljenju, mehaničkom guljenju, guljenju vodenom parom ili smrzavanjem, tim se postupkom može postići značajno uklanjanje njihovih ostataka (Đorđević i Đurović-Pejčev, 2016).

Guljenjem sirovog voća/povrća može se ukloniti više od $50 \%$ ostataka pesticida ukupno prisutnih u namirnici, tako da vrlo malo ostataka zaostane u jestivim dijelovima. To je vrlo bitno za voće koje se uobičajeno jede bez kore (Timme i WalzTylla, 2004). Postoje podatci u kojima se navodi i nemogućnost detektiranja ostataka pesticida u pulpi citrusa i ostalim jestivim dijelovima drugog voća (bananama, ananasu, kiviju i avokadu) nakon guljenja svježeg voća (Holland i sur., 1994). Guljenjem rajčica je došlo do značajnog smanjenja ostataka pesticida (lin- dana, $p, p$-DDT, dimetoata, profenofosa i pirimifos-metila) za $80,6 \%$ do 89,2\% (Abou-Arab, 1999b). U istraživanju Cengiza i suradnika (2006), prilikom guljenja krastavaca početni sadržaj organofosfornog pesticida diazinona se smanjio za 67,3\%, a u istraživanju Hassanzadeha i suradnika (2010) karbarila, karbamatnog insekticida, za 40\%. Glavni čimbenik koji bi mogao negativno utjecati na uklanjanje ostataka pesticida guljenjem je prodiranje pesticida u tkivo ploda, što ovisi o fizikalno-kemijskim svojstvima upotrjebljenog sredstva za zaštitu bilja te prirodi ploda (Amvrazi, 2011).

\section{Učinak termičkih postupaka obrade namirnica na sadržaj pesticida}

Termička obrada namirnica obuhvaća razne postupke: pasterizaciju, blanširanje, prokuhavanje, parenje, prženje, pečenje, sušenje i dehidraciju te zamrzavanje. S obzirom na to kako se svaki postupak razlikuje po primjenjenoj temperaturi, duljini trajanja, količini vode dodane prilikom provođenja postupka i tipu sustava (otvoren/zatvoren), doći će do različitog utjecaja na sadržaj ostataka pesticida u hrani (Timme i Walz-Tylla, 2004). Glavni fizikalno-kemijski procesi odgovorni za gubitak pesticida su termalna degradacija, isparavanje i/ili destilacija, dok će sama kemijska struktura pesticida odrediti koji će od tih procesa prevladati (Đorđević i Đurović-Pejčev, 2016). Neki pesticidi s obzirom na topljivost $\mathrm{u}$ vodi mogu migrirati iz sirove namirnice u vodu u kojoj se kuhaju, dok oni koji zaostanu u prehrambenom proizvodu su uglavnom lipofilni. U ekstremnim slučajevima prilikom kuhanja može doći i do degradacije ostataka pesticida i formiranja produkata koji mogu biti toksičniji od izvornih pesticida (Timme i Walz-Tylla, 2004).

\section{Pasterizacija - učinak na sadržaj pesticida}

Pasterizacija je komercijalna tehnika za očuvanje trajnosti prehrambenih proizvoda. Ona može uzrokovati smanjivanje količine raznih vrsta ostataka pesticida. Nakon pasterizacije mlijeka pri $65^{\circ} \mathrm{C}$ tijekom 30 minuta zabilježeni su gubici $p, p$ DDT-a i njegovih metabolita u rasponu od $15,6 \%$ do $58,8 \%$ (Jodral i sur., 1995). Pasterizacijom mlijeka pri $72{ }^{\circ} \mathrm{C}$ tijekom 15 sekundi došlo je do redukcije lindana od $65 \%$, dok je $63{ }^{\circ} \mathrm{C}$ tijekom 30 minuta rezultiralo sa $73 \%$ manje lindana u procesiranom mlijeku (Abou-Arab, 1999a).

Zbog većinom smanjenih udjela ostataka pesticida u pasteriziranom mlijeku, preporučuje se konzumacija ugrijanog mlijeka i mliječnih proizvoda, ako se sa sigurnošću ne zna sadrži li taj proizvod ostatke pesticida ili ne (Bajwa i Sandhu, 2014).

Blanširanje, parenje, prokuhavanje, kuhanje, prženje, pečenje i procesiranje u mikrovalnoj pećnici-učinak na sadržaj pesticida

Mnoga provedena istraživanja dokazuju da termički postupci imaju veliku ulogu u smanjivanju sadržaja ostataka pesticida. Tako je u istraživanju Hwanga i suradnika (2013) dokazan gubitak pesticida isoprotiolana i ftalida od 66\% i 79\% nakon kuhanja polirane riže te $88,7 \%$ i $92,9 \%$ nakon kuhanja smeđe riže. Prilikom prokuhavanja patlidžana, cvjetače i bamije došlo je do smanjenja organokloriranih ostataka u rasponu $39-55 \%, 57-61 \%$ te $32-47 \%$, sintetičkih piretroida za $37 \%, 40 \%$ 
i $42 \%$, a organofosfornih insekticida za redom $100 \%$, 92\% i $75 \%$ (Kumari, 2008). Procesi blanširanja tijekom 5 minuta kao i prženje patlidžana tijekom istog vremenskog perioda u potpunosti su uklonili ostatke profenofosa, organofosfornog pesticida, koji je prije procesiranja bio prisutan u količini $0,27 \mathrm{ppm}$ (Radwan i sur., 2005). U istraživanju Solimana (2001) proces blanširanja (nakon guljenja) krumpira, uzrokovao je smanjenje ostataka organokloriranih pesticida heksaklorobenzena, lindana i $p, p$-DDT-a za 22,9-28,3\%, a organofosfornih pesticida dimetoata, pirimifos-metila i malationa za 45,9-47,3\%. Prženje (nakon guljenja) je također pokazalo veći učinak na smanjenje ostataka organofosfornih pesticida $(48,7-53,4 \%)$ u odnosu na organoklorirane $(30,12-35,3 \%)$. Nagayama (2006) je istraživao odnos između postupka kuhanja i ostataka pesticida na različitim namirnicama. Ostaci organofosfornih pesticida na listovima zelenog čaja i u špinatu, jagodama i narančama bili su smanjeni kuhanjem, a stopa smanjenja bila je usko povezana s koeficijentom raspodjele oktanol-voda. U istraživanju (Reddy i sur., 2001) učinka procesa pranja vodom nakon kojeg slijedi kuhanje na pari, na sadržaj ostataka pesticida zaostalih na patlidžanu dokazano je smanjenje triazofosa u količini od $64-88 \%$, a ostataka lindana u količini od $42-56 \%$. Habiba i suradnici (1992) detektirali su ostatke profenofosa u sirovom (oguljenom) krumpiru u količini 11,48 ppm, dok su ostatke u krumpiru procesiranom u mikrovalnoj pećnici, pečenom u pećnici i prženom u ulju iznosile redom $0,22 \mathrm{ppm}, 0,19 \mathrm{ppm}$ i 0,004 ppm.

Pesticidi u hrani životinjskog podrijetla također se mogu u značajnoj mjeri ukloniti termičkim procesima. U istraživanju Sengupte i suradnika (2010) zabilježena je značajnija degradacija heksaklorbenzena, $p, p$-DDT-a, endosulfana, dimetoata i malationa u kravljem, kozjem i pilećem mesu nakon kuhanja u usporedbi s količinom nakon prženja mesa. Pretpostavlja se kako je kod kuhanja došlo do veće penetracije vodene pare unutar namirnice nego topline kod prženja, što je uzrokovalo veće smanjenje ostataka pesticida. Procesi koji uključuju toplinu mogu povećati isparavanje, hidrolizu ili neku drugu kemijsku razgradnju i na taj način utjecati na smanjenje ostataka pesticida (Holland i sur., 1994).

\section{Sušenje i dehidracija - učinak na sadržaj pesticida}

Sušenje je jedan od najstarijih i najjednostavnijih načina očuvanja hrane. Ono može biti provedeno na više načina: izlaganjem namirnica suncu, u pećnici ili u sušilici za hranu (Kaushik i sur., 2009). Glavni cilj sušenja je smanjenje sadržaja i aktiviteta vode u prehrambenim proizvodima, čime se automatski smanjuje mogućnost rasta mikroorganizama. U sušenim prehrambenim proizvodima udio vode je manji od $25 \%$ (Timme i Walz-Tylla, 2004). Sušenje se pokazalo kao učinkovito sredstvo za smanjivanje sadržaja ostataka nekih pesticida jer se prilikom sušenja eliminiraju iz namirnice isparavanjem (Đorđević i Đurović-Pejčev, 2016). No, može doći i do povišenja sadržaja ostataka pesticida jer se prilikom sušenja povećava udio suhe tvari u proizvodu i posljedično dolazi do koncentriranja ostataka (Timme i Walz-Tylla, 2004). Tako je u istraživanju Cabrasa i suradnika (1998) istraživan učinak dva različita procesa sušenja grožđica (u pećnici i na sunčevoj svjetlosti) na sadržaj ostataka različitih pesticida. Pokazalo se da ta dva procesa uzrokuju smanjenje ostataka pesticida za različite ispitane pesticide. Tako se sušenje na suncu pokazalo učinko- vitije za smanjenje ostataka dimetoata i vinklozolina, dok je sušenje u peći (uz postupak pranja) učinkovitije za iprodion i procimidon. Također, nakon sušenja u pećnici primijećeno je povećanje ostataka fosalona za 2,7 puta u grožđicama s obzirom na svježe voće, a sušenjem na sunčevom svjetlu ostataka iprodiona za 1,6 puta. U istraživanju koje je Lee (2001) proveo na klorpirifosom i fenitrotionom kontaminiranim crvenim paprikama, koji su nakon žetve detektirani u razinama 4 odnosno $10 \mathrm{ppm}$, sušenje na suncu ili vrućim zrakom uklonilo je 20$30 \%$ ostataka (nakon što je $30-40 \%$ pesticida uklonjeno vodom). Ostaci benalaksila, fosalona, metalaksila i procimidona na grožđicama sušenima na suncu bile su podjednake onima na sirovom neprocesiranom grožđu, iprodiona 1,6 puta više, a vinklozolina i dimetoata niže (Cabras i Angioni, 2000). U procesu sušenja u pećnici, ostaci benalaksila, metalaksila i vinklozolina su bili podjednaki u sirovom i procesiranom grožđu, a iprodiona i procimidona niži.

Osim o vrsti upotrjebljenog pesticida te načinu sušenja, na to kakav će učinak imati sušenje na ostatke pesticida značajnu ulogu ima i vrsta procesirane namirnice, kao i omjer površine i težine namirnice - što je on veći, smanjenje ostataka pesticida je veće (Amvrazi, 2011).

\section{Zamrzavanje - učinak na sadržaj pesticida}

Zamrzavanjem hrane se omogućuje dulje očuvanje kvalitete proizvoda, ali i usporavanje većine kemijskih reakcija unutar proizvoda. Što je čuvanje namirnice dulje, to će biti veće smanjenje ostataka pesticida (Ahmed i sur., 2011). Zamrzavanje rajčica na 3 dana rezultiralo je smanjenjem sadržaja ostataka pesticida lindana, $p, p$-DDT-a, dimetoata, profenofosa i pirimifos-metila za 5-9\%, na 6 dana 5-26\%, dok je nakon 12 dana smanjenje bilo 10-31\% (Abou-Arab, 1999b).

U Tablici 1 nalazi se pregled nekih provedenih istraživanja o utjecaju pripremnih tehnika i termičkih postupaka procesiranja na sadržaj ostataka pesticida u namirnicama. 
Tablica 1. Utjecaj pripremnih tehnika i termičkih postupaka procesiranja na sadržaj ostataka pesticida u namirnicama Table 1. Impact of preparation techniques and thermal processing methods on the content of pesticide residues in food

\begin{tabular}{|c|c|c|c|c|c|}
\hline način procesiranja / processing & $\begin{array}{l}\text { namirnica / } \\
\text { commodity }\end{array}$ & $\begin{array}{l}\text { pesticid / } \\
\text { pesticide }\end{array}$ & $\begin{array}{c}\text { \% smanjenja } \\
\text { ostataka } \\
\text { pesticida / \% } \\
\text { pesticide residue } \\
\text { dissipation }\end{array}$ & $\mathbf{P} f^{*}$ & $\begin{array}{l}\text { literatura / } \\
\text { reference }\end{array}$ \\
\hline \multirow[t]{2}{*}{ pranje vodom / washing with water } & \multirow{2}{*}{$\begin{array}{l}\text { rajčica / } \\
\text { tomatoe }\end{array}$} & $\begin{array}{l}\text { lindan / } \\
\text { lindane }\end{array}$ & 15 & & \multirow[t]{2}{*}{ Abou-Arab, 1999b } \\
\hline & & $p, p$-DDT & 9 & & \\
\hline \multirow{2}{*}{$\begin{array}{l}\text { pranje s } 10 \% \text {-tnom otopinom } \mathrm{NaCl} \text {-a / } \\
\text { washing with } 10 \% \mathrm{NaCl} \text { solution }\end{array}$} & \multirow{2}{*}{$\begin{array}{l}\text { rajčica / } \\
\text { tomatoe }\end{array}$} & $\begin{array}{l}\text { lindan / } \\
\text { lindane }\end{array}$ & 46 & & \multirow[t]{2}{*}{ Abou-Arab, 1999b } \\
\hline & & $p, p$-DDT & 27 & & \\
\hline \multirow[t]{2}{*}{$\begin{array}{l}\text { pranje s } 10 \% \text {-tnom octenom kiselinom / } \\
\text { washing with } 10 \% \text { acetic acid solution }\end{array}$} & \multirow[t]{2}{*}{$\begin{array}{l}\text { rajčica / } \\
\text { tomatoe }\end{array}$} & $\begin{array}{l}\text { lindan / } \\
\text { lindane }\end{array}$ & 47 & & \multirow[t]{2}{*}{ Abou-Arab, 1999b } \\
\hline & & $p, p-\mathrm{DDT}$ & 34 & & \\
\hline \multirow[t]{2}{*}{$\begin{array}{l}\text { smrzavanje na }-10{ }^{\circ} \mathrm{C} \text { na } 1 \text { dan } / \\
\text { freezing at }-10{ }^{\circ} \mathrm{C} \text { for } 1 \text { day }\end{array}$} & \multirow[t]{2}{*}{$\begin{array}{l}\text { rajčica / } \\
\text { tomatoe }\end{array}$} & $\begin{array}{l}\text { lindan / } \\
\text { lindane }\end{array}$ & 4 & & \multirow[t]{2}{*}{ Abou-Arab, 1999b } \\
\hline & & $p, p$-DDT & 2 & & \\
\hline \multirow{2}{*}{$\begin{array}{l}\text { smrzavanje na }-10{ }^{\circ} \mathrm{C} \text { na } 12 \text { dana / } \\
\text { freezing at }-10{ }^{\circ} \mathrm{C} \\
\text { for } 12 \text { days }\end{array}$} & \multirow{2}{*}{$\begin{array}{l}\text { rajčica / } \\
\text { tomatoe }\end{array}$} & $\begin{array}{l}\text { lindan / } \\
\text { lindane }\end{array}$ & 16 & & \multirow[t]{2}{*}{ Abou-Arab, 1999b } \\
\hline & & $p, p$-DDT & 13 & & \\
\hline guljenje / peeling & $\begin{array}{l}\text { krastavac / } \\
\text { cucumber }\end{array}$ & $\begin{array}{l}\text { karbaril / } \\
\text { carbaryl }\end{array}$ & 60 & & $\begin{array}{l}\text { Hassanzadeh i sur., } \\
2010 \text { / Hassanzadeh } \\
\text { et al., } 2010\end{array}$ \\
\hline \multirow{2}{*}{ guljenje / peeling } & \multirow{2}{*}{$\begin{array}{l}\text { mango / } \\
\text { mango }\end{array}$} & $\begin{array}{l}\text { dimetoat / } \\
\text { dimethoate }\end{array}$ & 100 & & \multirow{2}{*}{ Awasthi, 1993} \\
\hline & & $\begin{array}{l}\text { fention / } \\
\text { fenthion }\end{array}$ & 100 & & \\
\hline \multirow[t]{2}{*}{ kuhanje / boiling } & \multirow{2}{*}{$\begin{array}{l}\text { cvjetača / } \\
\text { cauliflower }\end{array}$} & endosulfan & 57 & & \multirow[t]{2}{*}{ Kumari, 2008} \\
\hline & & $p, p$-DDT & 61 & & \\
\hline \multirow{2}{*}{ kuhanje / boiling } & \multirow{2}{*}{$\begin{array}{l}\text { pileće meso / } \\
\text { chicken meat }\end{array}$} & $\begin{array}{l}\text { dimetoat / } \\
\text { dimethoate }\end{array}$ & 93 & & \multirow{2}{*}{$\begin{array}{l}\text { Sengupta i sur., } 2010 \\
\text { / Sengupta et al., } \\
2010\end{array}$} \\
\hline & & $\begin{array}{l}\text { malation / } \\
\text { malathion }\end{array}$ & 94 & & \\
\hline \multirow{2}{*}{ pečenje / baking } & \multirow{2}{*}{$\begin{array}{l}\text { pileće meso / } \\
\text { chicken meat }\end{array}$} & $\begin{array}{l}\text { dimetoat / } \\
\text { dimethoate }\end{array}$ & 63 & & \multirow{2}{*}{$\begin{array}{l}\text { Sengupta i sur., } 2010 \\
\text { / Sengupta et al., } \\
2010\end{array}$} \\
\hline & & $\begin{array}{l}\text { malation / } \\
\text { malathion }\end{array}$ & 67 & & \\
\hline
\end{tabular}




\begin{tabular}{|c|c|c|c|c|c|}
\hline \multirow{3}{*}{$\begin{array}{l}\text { sušenje na suncu / dried } \\
\text { by sunlight }\end{array}$} & \multirow{3}{*}{$\begin{array}{l}\text { grožđe / } \\
\text { grapes }\end{array}$} & $\begin{array}{c}\text { benalaksil / } \\
\text { benalaxyl }\end{array}$ & 20 & & \multirow{3}{*}{$\begin{array}{c}\text { Cabras i Angioni, } \\
2000 / \text { Cabras and } \\
\text { Angioni, } 2000\end{array}$} \\
\hline & & $\begin{array}{l}\text { iprodion / } \\
\text { iprodione }\end{array}$ & & 1,6 & \\
\hline & & $\begin{array}{l}\text { fosalon / } \\
\text { phosalone }\end{array}$ & 29 & & \\
\hline \multirow{3}{*}{$\begin{array}{l}\text { sušenje u pećnici / dried } \\
\text { by oven }\end{array}$} & \multirow{3}{*}{$\begin{array}{l}\text { grožđe / } \\
\text { grapes }\end{array}$} & $\begin{array}{c}\text { benalaksil / } \\
\text { benalaxyl }\end{array}$ & & 1,4 & \multirow{3}{*}{$\begin{array}{c}\text { Cabras i Angioni, } \\
2000 / \text { Cabras and } \\
\text { Angioni, } 2000\end{array}$} \\
\hline & & $\begin{array}{l}\text { iprodion / } \\
\text { iprodione }\end{array}$ & 53 & & \\
\hline & & $\begin{array}{l}\text { fosalon / } \\
\text { phosalone }\end{array}$ & & 2,8 & \\
\hline
\end{tabular}

$\mathrm{Pf}^{*}$ - eng. processing factor; omjer između količine ostataka pesticida u procesiranoj hrani i razine ostataka u sirovoj namirnici/ the ratio between pesticide residues in processed food and level of residues in raw food

\section{Zaključci}

Ostaci pesticida zaostaju u gotovo svim prehrambenim proizvodima. Na količinu ostataka uvelike utječe početna koncentracija pesticida, dok je lokalizacija samih ostataka u prehrambenim proizvodima različita i ovisi o prirodi i kemijskom sastavu pesticida, vrsti prehrambenog proizvoda i okolišnim uvjetima. Kada jednom pesticidi uđu u prehrambeni proizvod, oni se u njemu razgrađuju fotolizom, hidrolizom, oksidacijom, redukcijom, djelovanjem temperature i pH. Sadržaj ostataka pesticida zaostao u prehrambenom proizvodu se može mijenjati i prilikom procesiranja, a raspon u kojem će se sadržaj promijeniti ovisi o kemijskom sastavu ostataka pesticida, njihovoj topljivosti u vodi, lokalizaciji unutar namirnice, vrsti prehrambenog proizvoda u kojem se nalaze i načinu procesiranja. Koraci procesiranja kroz koje prehrambeni proizvod može prolaziti se kreću od onih najjednostavnijih kao što je pranje, guljenje, blanširanje, kuhanje, pečenje, prženje ili zamrzavanje do onih kompliciranijih koji se provode uglavnom u industrijama i uključuju skup različitih koraka procesiranja. Kontaktni pesticidi, za razliku od pesticida sistemičnog načina djelovanja, u većoj mjeri mogu biti uklonjeni ili njihova koncentracija može biti smanjena procesima pranja, guljenja, kuhanja, blanširanja, prženja, pečenja, pasterizacije ili sterilizacije. Zbog težeg uklanjanja nekih vrsta pesticida i njihovog zaostajanja u prehrambenim proizvodima, potrebno je dodatno razmotriti njihovu upotrebu. Cilj je osigurati isplativu proizvodnju prehrambenih proizvoda bez nametnika ili bolesti, ali ona se treba provoditi uz optimalno i ispravno korištenje pesticida. $\mathrm{Na}$ taj način neće doći do kontaminacije prehrambenih proizvoda pesticidima koji bi mogli ozbiljno narušiti ljudsko zdravlje.

\section{Literatura}

Abou-Arab A.A.K. (1999a) Effects of processing and storage of dairy products on lindane residues and metabolites. Food Chemistry, 64 (4) 467-473.

Abou-Arab A.A.K. (1999b) Behavior of pesticides in tomatoes during commercial and home preparation. Food Chemistry, 65 (4) 509-514.
Ahmed A., Randhawa M.A., Yusuf M.J., Khalid N. (2011) Effect of processing on pesticide residues in food crops - A review. Journal of Agricultural Research, 49 379-390.

Amvrazi E.G. (2011) Fate of Pesticide Residues on Raw Agricultural Crops after Postharvest Storage and Food Processing to Edible Portions. U: Stoytcheva M. (ed): Pesticides Formulations, Effects, Fate, str. 575-589. Intech, Rijeka, Hrvatska.

Awasthi, M. D. (1993) Decontamination of insecticide residues on mango by washing and peeling. Journal of Food Science Technology, 30 (2) 132-133.

Bajwa U., Sandhu S. K. (2014) Effect of handling and processing on pesticide residues in food- a review. Journal of Food Science and Technology, 51 (2) 201-220.

Cabras P., Angioni A., Garau V.L., Menelli E.V., Cabitza F., Pala M. (1998) Pesticide residue in raisin processing. Journal of Agricultural and Food Chemistry, 46 2309-2311.

Cabras P., Angioni A. (2000) Pesticide residues in grapes, wine and their processing products. Journal of Agricultural and Food Chemistry, 48 (4) 967-973.

Cabras P. (2003) Pesticides: Toxicology and Residues in Food. U: D'Mello J.P.F. (ed): Food safety: Contaminants and Toxins, str. 91-120. CABI Publishing, Oxon, UK.

Cengiz M.F., Certel M., Göçmen H. (2006) Residue contents of DDVP (dichlorvos) and diazinon applied on cucumbers grown in greenhouses and their reduction by duration of a pre-harvest interval and post-harvest culinary applications. Food Chemistry, 98 127-135.

Đorđević T., Đurović-Pejčev R. (2016) Food processing as a means for pesticide residue dissipation. Pesticides and Phytomedicine, 31 (3-4) 89-105.

EL-Saeid M.H., Selim M.T. (2016) Effect of food processing on reduction of pesticide residues in vegetables. Journal of Applied Life Sciences International, 8 (1) 1-6.

FAO (2005) International Code of Conduct on the Distribution and Use of Pesticides. FAO - Food and Agriculture Organization of the United Nations, Rim. Dostupno na: http:// www.fao.org/docrep/018/a0220e/a0220e00.pdf. Pristupljeno: 21.05.2018.

González-Rodrígez R.M., Rial-Otero R., Cancho-Grande B., Gonzalez-Barreiro C., Simal-Gándara J. (2011) A review 
on the fate of pesticides during the processes within the foodproduction chain. Critical Reviews in Food Science and Nutrition, 51 99-114.

Habiba R.A., Ali H.M., Ismail S.M.M. (1992) Biochemical effects of profenofos residues in potatoes. Journal of Agricultural and Food Chemistry, 40 (10) 1852-1855.

Hassanzadeh N., Bahramifar N., Esmaili-Sari A. (2010) Residue content of carbaryl applied on greenhouse cucumbers and its reduction by duration of a pre-harvest interval and postharvest household processing. Journal of the Science of Food and Agriculture, 90 2249-2253.

Holland P.T., Hamilton D., Ohlin B., Skidmore M.W. (1994) Effects of storage and processing on pesticide residues in plant products. Pure and Applied Chemistry, 66 (2) 335-356.

Hu R., Huang X., Huang J., Li Y., Zhang C., Yin Y., Chen Z., Jin Y., Cai J., Cui F. (2015) Long- and short-term health effects of pesticide exposure: A cohort study from China. PLoS One, 10 (6): e0128766.

Hwang L.-H., Kim A.-K., Jung B.-K., Lee J.-K., Shin J.M., Park Y.-H., Park H.-W., Kim M.-J., Park K.-A., Yun E.-S., Kim M.-S. (2013) Removal of pesticides during washing and cooking of rice. Journal of Food Hygiene and Safety, 28 (1) 31-35.

Jodral M., Martinez P., Angulo R., Gallego M.C., Pozo R. (1995) Effect of milk pasteurization on DDT and its metabolites. Alimentaria, 266 25-28.

Kaushik G., Satya S., Naik S.N. (2009) Food processing a tool to pesticide residue dissipation - A review. Food Research International, 42 26-40.

Kumari B. (2008) Effects of household processing on reduction of pesticide residues in vegetables. ARPN Journal of Agricultural and Biological Science, 3 (4) 46-51.

Lee M.G. (2001) Reduction of chlorpyriphos and fenitrothion residues in red pepper peel by washing and drying. Food Science and Biotechnology, 10 429-437.

Łozowicka B., Jankowska M. (2016) Comparison of the effects of water and thermal processing on pesticide removal in selected fruits and vegetables. Journal of Elementology, 21 (1) $99-111$.

Murati T., Šimić B., Kniewald J., Pleadin J., Kmetič I. (2014) Organoklorovi insekticidi - mehanizam toksičnog djelovanja. Croatian Journal of Food Technology, Biotechnology and Nutrition,9 (3-4) 97-109.

Nagayama T. (2006) Behavior of residual organophosphorus pesticides in foodstuffs during leaching or cooking. Journal of Agricultural and Food Chemistry, 44 2388-2393.

Nasreddine L., Parent-Massin D. (2002) Food contamination by metals and pesticides in the European Union. Should we worry? Toxicology Letters, 127 29-41.

NPIC (1999) Pesticide Formulations. NPIC - National Pesticide Information Center, Corvallis. Dostupno na: http://npic. orst.edu/factsheets/formulations.html. Pristupljeno: 10.5.2018.

Puntarić D., Miškulin M., Bošnir J. (2012) Zdravstvena ekologija. Medicinska naklada, Zagreb, Hrvatska. str. 113-122, 138, 147-149, 288-290.

Radwan M.A., Abu-Elamayem M.M., Shiboob M.H., Abdel-Aal A. (2005) Residual behaviour of profenofos on some field-grown vegetables and its removal using various washing solutions and household processing. Food and Chemical Toxicology, 43 (4) 553-557.
Reddy N.K., Sultan M.A., Reddy D.J., Babu T.R. (2001) Dissipation and decontamination of triazophos and lindane in brinjal. Pestology, 25 51-54.

Sengupta D., Aktar M.W., Alam S., Chowdhury A. (2010) Impact assessment and decontamination of pesticides from meat under different culinary processes. Environmental Monitoring and Assessment, 169 37-43.

Scholz R., Herrmann M., Michalski B. (2017) Compilation of processing factors and evaluation of quality controlled data of food processing studies. Journal of Consumer Protection and Food Safety, 12 (1) 3-14.

Soliman K.M. (2001) Changes in concentration of pesticide residues in potatoes during washing and home preparation. Food and Chemical Toxicology, 39 (8) 887-891.

Timme G., Walz-Tylla B. (2004) Effects of Food Preparation and Processing on Pesticide Residues in Commodities of Plant Origin. U: Hamilton D., Crossley S. (ed): Pesticide Residues in Food and Drinking Water: Human Exposure and Risks, str. 121-146. John Wiley \& Sons, Inc., Hoboken, New Jersey, SAD. 